\title{
Biotech as an employer
}

Stacy Lawrence

According to a recent survey in Science (http://sciencecareers. sciencemag.org/career_development/previous_issues/articles/2006_11_ 03/life_scientists_report_rising_salaries_and_high_job_satisfaction/), on average, life science PhDs working in industry made $\$ 116,000$ last year-up $\sim 10 \%$ over 2005. Median salaries, which filter out the extremes,

\section{Employment at public biotech companies by region}

Of the almost 200,000 employees at public biotech companies, about $70 \%$ are in the US.

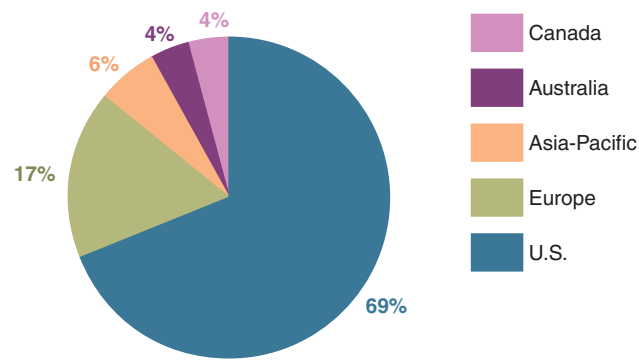

Based on 2005 data, except for US which is 2004. Source: Ernst \& Young

\section{Median salary by highest degree earned}

Advanced medical and pharmacology degrees (and even a non-science PhD!) carry a substantial premium over a science PhD.

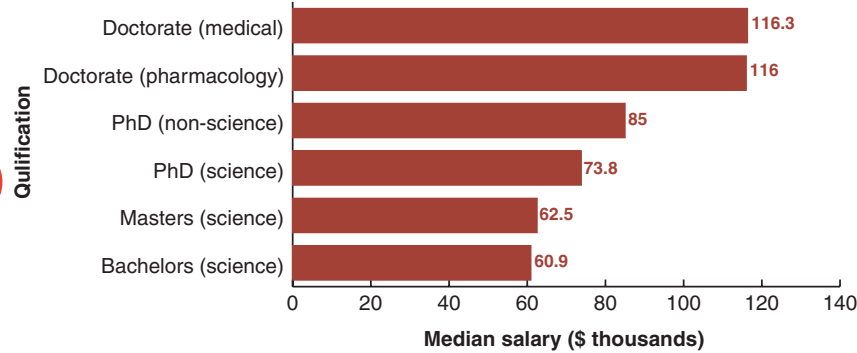

Data for 2006. Source: The Scientist

Distribution of biotech employees at private and public companies Percentage of

\begin{tabular}{lccc} 
& Private employees & Public employees & $\begin{array}{c}\text { biotech employees } \\
\text { at private firms }\end{array}$ \\
\hline United States & 75,767 & 105,362 & 42 \\
Germany & 10,445 & 3,794 & 73 \\
United Kingdom & 8,112 & 10,167 & 44 \\
France & 4,790 & 3,422 & 58 \\
Denmark & 3,255 & 15,155 & 18 \\
Switzerland & 2,995 & 2,991 & 56 \\
Sweden & 2,873 & 1,434 & 67 \\
Netherlands & 1,596 & 770 & 67 \\
Belgium & 1,265 & 1,342 & 49 \\
Finland & 1,010 & 933 & 77 \\
Norway & 835 & 50 & 94 \\
Europe & 36,670 & 40,543 & 47 \\
Total & 112,437 & 145,905 & 54 \\
\hline
\end{tabular}

Data for 2004. Source: Critical I are more modest: for doctorate-level scientists working in biotech, a salary of $\sim \$ 100,000$ falls around the middle of the pack (almost one-third higher than in 2001). Globally, >130,000 R\&D staff work in biotech and $\sim 200,000$ people are employed in research and business capacities at public biotech companies.

\section{Life science median salary by position and US region}

San Francisco, with its high cost of living and strong life sciences sector, ranks the highest in pay across the board.

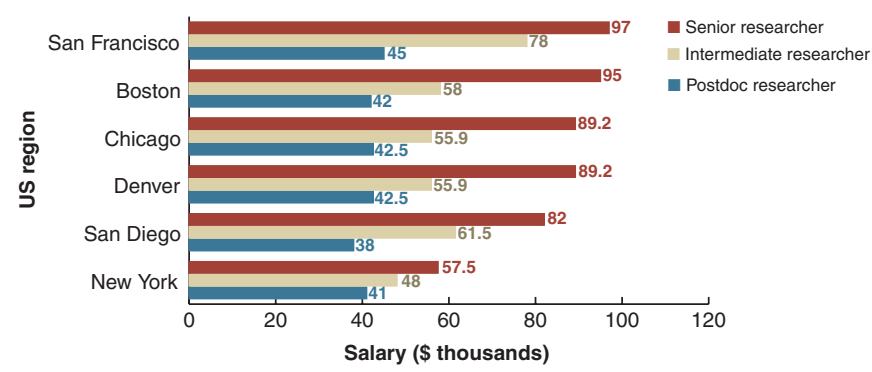

Data for 2006. Source: The Scientist

\section{Number of biotech R\&D employees}

According to OECD, $>130,000$ employees are engaged around the globe in biotech R\&D, $\sim 56 \%$ of them in the US.

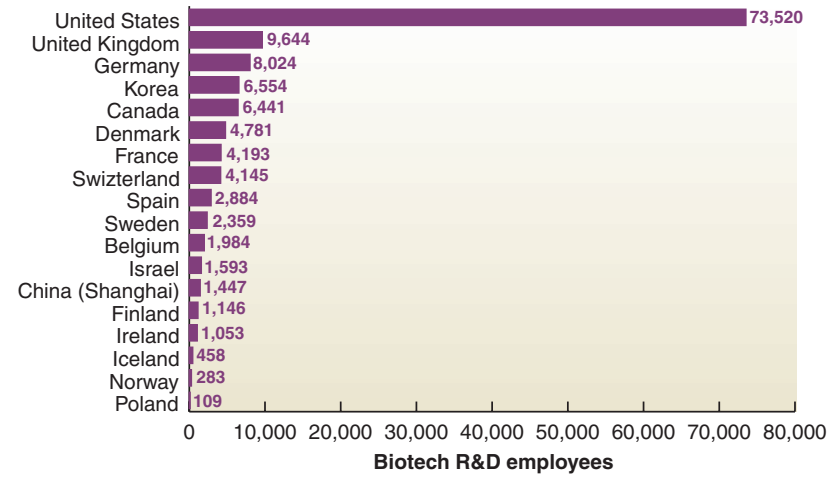

Data for 2003 and 2004. Source: Organisation for Economic Co-operation

Employee productivity at big biotech versus pharma

\begin{tabular}{lrc} 
Type of employer & Number of employees & $\begin{array}{c}\text { Company revenue per } \\
\text { employee (\$ thousands) }\end{array}$ \\
\hline Top five biotech & 14,300 & 841 \\
Amgen & 7,646 & 868 \\
Genentech & 7,000 & 371 \\
Genzyme & 5,400 & 356 \\
Chiron & 4,266 & 557 \\
Biogen Idec & & \\
Top five pharma & 115,000 & 446 \\
Pfizer & 109,900 & 461 \\
Johnson \& Johnson & 62,600 & 351 \\
Merck & 44,500 & 329 \\
Eli Lilly & 43,000 & 447 \\
Bristol-Myers Squibb & &
\end{tabular}

